\title{
U.S. Geological Survey EDMAP Program Training the Next Generation of Geologic Mappers
}

EDMAP is an interactive and meaningful program for university students to gain experience and knowledge in geologic mapping while contributing to national efforts to map the geology of the United States. It is a matching-funds grant program with universities and is one of the three components of the congressionally mandated U.S. Geological Survey (USGS) National Cooperative Geologic Mapping Program. Geology professors whose specialty is geologic mapping request EDMAP funding to support upper-level undergraduate and graduate students at their colleges or universities in a 1-year mentor-guided geologic mapping project that focuses on a specific geographic area. Every Federal dollar that is awarded is matched with university funds.

EDMAP is invaluable not only because it contributes to national geologic mapping efforts but also because it helps fund academic research, thoroughly prepares students for real-world careers in the geosciences, and gives participants a competitive edge in the job market.

- Students participating in the EDMAP Program receive training and first-hand field experience in geologic mapping and thus acquire skills useful in many geoscience fields.

- EDMAP geology professors and their students frequently work closely with State geological surveys and U.S. Geological Survey geologists.

- Student work contributes to geologic mapping of the United States.

"Over the past 15 years EDMAP has produced some of the best geologic mappers in the Nation. The thing that excites me the most is some of our earliest students have gone on to mentor several younger generations of EDMAP students. EDMAP is the gift that keeps on giving."

- Peter Lyttle, Program Coordinator

National Cooperative Geologic Mapping Program
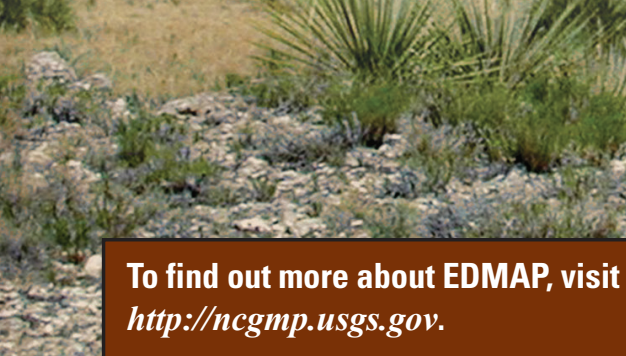

To find out more about EDMAP, visit http://ncgmp.usgs.gov.
- So far, EDMAP has benefited 149 universities and more than 935 students from geoscience departments across the Nation.

- Results from a recent EDMAP participant survey show that 95 percent of the respondents either pursued higher degrees or obtained jobs in the geosciences.

- Surveyed participants consider the program to be a great opportunity and one that was enjoyable and highly valuable to their careers.

\section{Application Process}

Cooperative agreements are awarded based on a dollarfor-dollar match through an annual, competitive proposal process. Per-project funding available for graduate projects each fiscal year is $\$ 17,500$; for undergraduate projects, it is $\$ 10,000$. A peer-review panel consisting of university faculty, State Geologists, and USGS representatives determines which proposals will be awarded cooperative agreements.

- Applications for professors and students interested in participating in this program are solicited annually in September by the EDMAP Program Announcement, which is available online at $h t t p: / / g r a n t s . g o v$.

- To access the EDMAP Program Announcement in September, $\log$ on to http://grants.gov, select Find Grant Opportunities, then select Basic Search, and type in the keyword "EDMAP."

- Applications are due online by the announcement due date to the USGS Office of Acquisitions and Grants through http://grants.gov. 


\section{Alabama}

Auburn University

University of South Alabama

\section{Alaska}

University of Alaska-Fairbanks

\section{Arizona}

Arizona State University

Northern Arizona University

The University of Arizona

\section{Arkansas}

University of Arkansas-Fayetteville

\section{California}

California Institute of Technology

California Polytechnic State University

California State University-Long Beach

California State University-Northridge

California State University-Sacramento

Humboldt State University

San Diego State University

San Francisco State University

San José State University

Stanford University

University of California-Davis

University of California-Santa Barbara

University of Southern California

\section{Colorado}

Colorado School of Mines

Colorado State University

Fort Lewis College

Mesa State College

Western State College of Colorado

\section{Connecticut}

Eastern Connecticut State University

\section{District of Columbia}

The George Washington University

\section{Florida}

The Florida State University

\section{Georgia}

Columbus State University

The University of Georgia

\section{Idaho}

Boise State University

Brigham Young University-Idaho

Idaho State University

University of Idaho

\section{Illinois}

Illinois State University

Northeastern Illinois University

Northern Illinois University

Northwestern University

Southern Illinois University

University of Illinois

Western Illinois University

\section{Indiana}

Purdue University

\section{lowa}

Simpson College

The University of Iowa

University of Northern Iowa

\section{Kansas}

The University of Kansas

Wichita State University

\section{Kentucky}

Eastern Kentucky University

Morehead State University
Northern Kentucky University

University of Kentucky

\section{Louisiana}

Centenary College of Louisiana

Louisiana State University

The University of Louisiana at Monroe

The University of New Orleans

\section{Maine}

Bates College

The University of Maine

University of Southern Maine

\section{Massachusetts}

Boston College

University of Massachusetts-Amherst

\section{Michigan}

Central Michigan University

Grand Valley State University

Michigan State University

Michigan Technological University

University of Michigan-Dearborn

Wayne State University

Western Michigan University

\section{Minnesota}

University of Minnesota

University of St. Thomas

\section{Mississippi}

The University of Mississippi

\section{Missouri}

Missouri State University

Southeast Missouri State University

University of Missouri

\section{Montana}

Montana State University

Montana Tech of the University of Montana

Rocky Mountain College

The University of Montana

\section{Nebraska}

University of Nebraska-Lincoln

\section{Nevada}

University of Nevada-Las Vegas

University of Nevada-Reno

\section{New Hampshire}

Dartmouth College

Keene State College

The University of New Hampshire

\section{New Mexico}

New Mexico Institute of Mining and Technology

New Mexico State University

The University of New Mexico

\section{New York}

CUNY-Brooklyn College

CUNY-Queens College

SUNY-College at Oneonta

SUNY-The College at Brockport

SUNY-University at Albany

SUNY-University at Buffalo

University of Rochester

\section{North Carolina}

Appalachian State University

Duke University

East Carolina University

North Carolina State University

The University of North Carolina-Chapel Hill

The University of North Carolina-Charlotte

The University of North Carolina-Wilmington

\section{North Dakota}

Minot State University

The University of North Dakota

\section{Ohio}

Kent State University

Miami University

Ohio University

The Ohio State University

The University of Toledo

University of Cincinnati

\section{Oklahoma}

Oklahoma State University

The University of Oklahoma

\section{Oregon}

Oregon State University

Portland State University

University of Oregon

\section{Pennsylvania}

Lehigh University

Pennsylvania State University

University of Pittsburgh

\section{Puerto Rico}

University of Puerto Rico

\section{South Carolina}

Clemson University

Coastal Carolina University

College of Charleston

University of South Carolina

\section{South Dakota}

South Dakota School of Mines \& Technology

\section{Tennessee}

Tennessee Tech University

The University of Memphis

The University of Tennessee-Chattanooga

The University of Tennessee-Knoxville

\section{Texas}

Texas Tech University

The University of Texas at Arlington

The University of Texas at Austin

\section{Utah}

Brigham Young University

Southern Utah University

The University of Utah

Utah State University

\section{Vermont}

Castleton State College

Middlebury College

\section{Virginia}

James Madison University

Radford University

The College of William and Mary

Virginia Wesleyan College

\section{Washington}

Central Washington University

Eastern Washington University

University of Washington

Washington State University

Western Washington University

\section{West Virginia}

West Virginia University

\section{Wisconsin}

University of Wisconsin-Eau Claire

University of Wisconsin-Madison

\section{Wyoming}

University of Wyoming 